\title{
Review \\ Recent developments in anti-rheumatic drugs in pediatrics: treatment of juvenile idiopathic arthritis
}

\author{
Kristen Hayward and Carol A Wallace
}

Division of Rheumatology, University of Washington School of Medicine, Seattle Children's Hospital, 4800 Sandpoint Way, NE MS R-5420, Seattle, WA 98105, USA

Corresponding author: Carol A Wallace, cwallace@u.washington.edu

Published: 23 February 2009

This article is online at http://arthritis-research.com/content/11/1/216

(c) 2009 BioMed Central Ltd
Arthritis Research \& Therapy 2009, 11:216 (doi:10.1186/ar2619)

chronic uveitis associated with JIA) $[3,4]$. In the case of the systemic-onset form of JIA (SOJIA), untreated disease may even result in multiple organ failure and death.

Twenty years ago it was commonly believed that childhoodonset arthritis might subside in adulthood. Recent studies, however, have demonstrated that sustained resolution of disease occurs in only a small minority of JIA patients (as many as $50 \%$ of children with JIA enter adulthood with ongoing, active disease) [3]. Additional information from a recent large, multicenter, retrospective study indicates that patients diagnosed with JIA experience a chronic course involving cycling of disease between active and inactive states over the course of years. Although 196 out of $437 \mathrm{JIA}$ patients followed over a median of 7 years achieved a period of 1 year without any JIA symptoms off all medications, less than $20 \%$ of patients had two consecutive years without symptoms and only $4 \%$ had a 5-year disease-free period [5]. These studies indicate that many patients diagnosed with JIA will be exposed to extended periods of medications throughout their lifetimes, and underscore the importance of understanding current trends in the medical management of children with JIA.

Historically, the management of JIA has relied on nonsteroidal medications with slow addition of traditional diseasemodifying anti-rheumatic drugs (DMARDs) such as methotrexate or sulfasalazine, with avoidance of systemic corticosteroids. More recently, intra-articular corticosteroid injections have been included in the treatment approach. Several recent articles present thorough reviews of the literature surrounding traditional anti-rheumatic treatments in JIA [6-8]. These medications are effective in reducing symptoms and can result in disease remission in approxi-

ACR Pedi = American College of Rheumatology Pediatric; DMARD = disease-modifying anti-rheumatic drug; FC = crystallizable fragment; FDA = Food and Drug Administration; IL = interleukin; JIA = juvenile idiopathic arthritis; MAS = macrophage activation syndrome; RA = rheumatoid arthritis; $\mathrm{SAE}=$ serious adverse event; SOJIA = systemic-onset juvenile idiopathic arthritis; TNF = tumor necrosis factor. 
Table 1

\begin{tabular}{|c|c|}
\hline Category & Characteristics \\
\hline Systemic onset & Arthritis in one or more joints, 2 weeks of fever, plus $\geq 1$ of: rash, hepatosplenomegaly, lymphadenopathy \\
\hline Oligoarthritis & $\begin{array}{l}\text { Arthritis affecting one to four joints for first } 6 \text { months of disease: persistent, affects } \leq 4 \text { joints throughout disease } \\
\text { course; extended, affects }>4 \text { joints after the first } 6 \text { months }\end{array}$ \\
\hline $\begin{array}{l}\text { Polyarthritis, rheumatoid } \\
\text { factor-negative }\end{array}$ & Arthritis affecting five or more joints in the first 6 months, negative rheumatoid factor \\
\hline $\begin{array}{l}\text { Polyarthritis, rheumatoid } \\
\text { factor-positive }\end{array}$ & $\begin{array}{l}\text { Arthritis affecting five or more joints in the first } 6 \text { months, positive rheumatoid factor (on two separate occasions } \\
\text { at least } 3 \text { months apart) }\end{array}$ \\
\hline Psoriatic arthritis & Arthritis plus psoriasis in child - or two out of three of: dactylitis, nail pitting, psoriasis in first-degree relative \\
\hline Enthesitis-related arthritis & $\begin{array}{l}\text { Arthritis and enthesitis - or arthritis or enthesitis and two out of: sacroiliac joint involvement, HLA-B27-positive, } \\
\text { male }>6 \text { years, acute anterior uveitis, ankylosing spondylitis, inflammatory bowel disease plus sacroilitis in } \\
\text { first-degree relative }\end{array}$ \\
\hline Undifferentiated arthritis & Arthritis not meeting criteria for one of above categories or fitting more than one of the above groups \\
\hline
\end{tabular}

Data from Petty and colleagues [2].

mately $15 \%$ of JIA patients. Patients with polyarticular and systemic JIA, however, often have disease refractory to traditional agents and/or face significant potential adverse effects associated with chronic steroid usage required to keep the disease under control [5].

With the advent of biologic therapeutics over the past 10 years there has been a rapid increase in the number of and types of agents available for treatment of JIA. While much of the treatment of childhood arthritis builds on experience gained from adult patients and studies, certain unique considerations arise in the treatment of children with JIA. In particular, issues of growth and development are important in developing appropriate treatment regimens. Furthermore, given the chronic nature of JIA and the potential for long-term medication exposure, treatment of children with JIA involves a careful balancing of risks and benefits of interventions.

The present article will focus on recent advances in the medical treatment of JIA. In particular, the existing literature on the use of biologic agents in oligoarticular JIA, polyarticular JIA and SOJIA will be explored in detail. Novel treatments for JIA currently under development will be discussed, as well as future directions in the research of medical therapy for children with JIA.

\section{Goals of juvenile idiopathic arthritis treatment}

There is currently no cure for JIA. The primary goals of medical therapy are to eliminate active disease, to normalize joint function, to preserve normal growth and to prevent longterm joint damage. In the research arena, the gold standard to document response to pharmacologic agents has been the pediatric core set, which is used to assess the level of American College of Rheumatology response (Table 2). This scale incorporates responses within several dimensions, including physician global assessment, active joint count, number of joints with limited range of motion, inflammatory markers and patient or parent assessments. Although several response levels are reported, only the American College of Rheumatology Pediatric (ACR Pedi) 30 response has been prospectively validated.

Given the increased emphasis on the achievement of complete disease control, preliminary clinical criteria have recently been developed that define the disease states of inactive disease and clinical remission (Table 3 ). In addition to these criteria, the use of outcome measures that incorporate child and parent reports of quality of life are important tools and remain an area of ongoing development [9].

\section{Biologic agents}

Advances in the understanding of the immune system have shed light on pathways involved in inflammation and selftolerance that provide new targets for treatment of rheumatologic conditions. Biologic agents have been designed to target key cytokines implicated in JIA, including TNF $\alpha, \mathrm{IL}-1$, IL-6 as well as signaling molecules involved in the regulation of B-cell and T-cell lymphocyte responses (Table 4).

Although promising results have been demonstrated with these medications, the blockade of such important biologic pathways necessitates careful safety monitoring. In particular, use of biologic medications in the pediatric population raises questions around infection risks, responses to vaccinations, possible neurologic side effects and long-term effects on immune surveillance and possible risks of malignancy. The use of biologics in combination is associated with increased infection risks and is not recommended by the US Food and Drug Administration (FDA). 
Table 2

\section{Pediatric core set criteria for improvement in juvenile idiopathic arthritis}

1.

2.

3.

4.

5.

6.

American College of Rheumatology Pediatric 30 response

American College of Rheumatology Pediatric 50 response

American College of Rheumatology Pediatric 70 response
Physician's global assessment of overall disease activity

Parent of patient global assessment of overall well-being

Functional ability

Number of joints with active arthritis

Number of joints with limited range of motion

Erythrocyte sedimentation rate

A minimum of $30 \%$ improvement from baseline in a minimum of three out of six components, with a worsening by $>30 \%$ in no more than one component

Requires $50 \%$ improvement in three out of six components with worsening of $30 \%$ in no more than one component

Requires $70 \%$ improvement in three out of six components with worsening of $30 \%$ in no more than one component

Data from Giannini and colleagues [50] and Brunner and colleagues [51].

Table 3

\section{Criteria for inactive disease and clinical remission in juvenile idiopathic arthritis ${ }^{a}$}

Criteria

No active synovitis

No fever, rash, serositis, splenomegaly, or generalized lymphadenopathy attributable to juvenile idiopathic arthritis

No active uveitis

Normal erythrocyte sedimentation rate and/or C-reactive protein

Physician's global assessment of disease activity indicates no active disease

Inactive disease

Requires that the patient satisfy all of the above criteria

Clinical remission on medication

Six continuous months of inactive disease on medication

Clinical remission off of medication

12 continuous months of inactive disease off all anti-arthritis and anti-uveitis medications

aApplies to oligoarticular, polyarticular (rheumatoid factor-negative, rheumatoid factor-positive) and systemic juvenile idiopathic arthritis at this time. Table reproduced with permission from Ringold S, Wallace CA: Measuring clinical response and remission in juvenile idiopathic arthritis. Curr Opin Rheumato/ 2007, 19:471-476 [9]. Data from Wallace and collegues [52].

\section{TNF $\alpha$ antagonists}

TNF $\alpha$ is a potent proinflammatory cytokine. Overproduction of TNF $\alpha$ has been implicated in mouse models of inflammatory arthritis, and elevated TNF levels have been identified in plasma and synovial fluid in patients with active arthritis, including children with JIA [10].

Three biologic agents targeting TNF $\alpha$ are being used currently in the treatment of JIA.

\section{Etanercept}

Etanercept (Enbrel) is a fusion protein consisting of the extracellular domain of the TNF $\alpha$ receptor combined with the Fc portion of the human immunoglobulin molecule. Etanercept binds to soluble TNF $\alpha$ and thus decreases downstream TNF $\alpha$ receptor-mediated signaling. Etanercept was the first TNF $\alpha$ antagonist to be approved for use in JIA in 1999, and recently has received FDA approval for treatment of moderate to severe polyarticular JIA in patients as young as 2 years old.
To date there has only been one randomized controlled trial of etanercept for the treatment of JIA. Lovell and colleagues enrolled 69 patients with DMARD refractory polyarticular JIA in a multicenter, placebo-controlled trial employing a drugwithdrawal design, followed by ongoing open-label extension trials [11]. The randomized phase of this trial indicated that patients randomized to continued etanercept therapy $(0.4 \mathrm{mg} / \mathrm{kg}$ subcutaneously twice a week or $0.8 \mathrm{mg} / \mathrm{kg}$ subcutaneously once a week) had a significantly longer median time to disease flare than patients randomized to placebo after an initial 3-month run-in treatment with etanercept (116 days versus 28 days).

The most recent open-label extension update from this trial provided information on 318 patient-years of etanercept therapy, including up to 8 years of continuous treatment for some participants. In 11 patients who continued etanercept therapy for 8 years, the ACR Pedi 70 response rate was $100 \%$ [12]. This marked response, however, should be 
Table 4

\begin{tabular}{|c|c|c|c|c|}
\hline Drug & Target & FDA approval for JIA & Route & Dosage options \\
\hline $\begin{array}{l}\text { Etanercept } \\
\text { (Enbrel) }\end{array}$ & TNF $\alpha$ & $\begin{array}{l}\text { Polyarticular JIA ages } \\
2 \text { years and older }\end{array}$ & $\begin{array}{l}\text { Subcutaneous } \\
\text { injection }\end{array}$ & $\begin{array}{l}0.8 \mathrm{mg} / \mathrm{kg} / \text { dose once a week, } \\
\text { maximum } 50 \mathrm{mg} / \text { dose }\end{array}$ \\
\hline $\begin{array}{l}\text { Infliximab } \\
\text { (Remicade) }\end{array}$ & TNF $\alpha$ & No & $\begin{array}{l}\text { Intravenous } \\
\text { infusion }\end{array}$ & $\begin{array}{l}6 \text { to } 10 \mathrm{mg} / \mathrm{kg} / \mathrm{dose} \text { weeks } 0,2 \\
\text { and } 6 ; \text { then every } 4 \text { to } 8 \text { weeks }\end{array}$ \\
\hline $\begin{array}{l}\text { Adalimumab } \\
\text { (Humira) }\end{array}$ & TNF $\alpha$ & $\begin{array}{l}\text { Polyarticular JIA ages } \\
4 \text { years and older }\end{array}$ & $\begin{array}{l}\text { Subcutaneous } \\
\text { injection }\end{array}$ & $\begin{array}{l}24 \mathrm{mg} / \mathrm{m}^{2} \text { every } 2 \text { weeks, } \\
\text { maximum } 40 \mathrm{mg} / \text { dose }\end{array}$ \\
\hline $\begin{array}{l}\text { Anakinra } \\
\text { (Kineret) }\end{array}$ & IL-1 & No & $\begin{array}{l}\text { Subcutaneous } \\
\text { injection }\end{array}$ & $\begin{array}{l}1 \text { to } 2 \mathrm{mg} / \mathrm{kg} / \mathrm{day} \text {, } \\
\text { maximum } 100 \mathrm{mg} / \text { dose }\end{array}$ \\
\hline $\begin{array}{l}\text { Rilonacept } \\
\text { (IL-1 Trap) }\end{array}$ & $\mathrm{IL}-1$ & No & $\begin{array}{l}\text { Subcutaneous } \\
\text { injection }\end{array}$ & 2.2 to $4.4 \mathrm{mg} / \mathrm{kg}$ once a week \\
\hline $\begin{array}{l}\text { Abatacept } \\
\text { (Orencia) }\end{array}$ & $\begin{array}{l}\text { Cytotoxic } \\
\text { T-lymphocyte- } \\
\text { associated antigen } 4\end{array}$ & $\begin{array}{l}\text { Polyarticular JIA ages } \\
6 \text { years and older }\end{array}$ & $\begin{array}{l}\text { Intravenous } \\
\text { infusion }\end{array}$ & $\begin{array}{l}10 \mathrm{mg} / \mathrm{kg} \text { weeks } 0,2 \text { and } 4 ; \\
\text { then every } 4 \text { weeks, } \\
\text { maximum } 1,000 \mathrm{mg} / \text { dose }\end{array}$ \\
\hline $\begin{array}{l}\text { Rituximab } \\
\text { (Rituxan) }\end{array}$ & CD20 & No & $\begin{array}{l}\text { Intravenous } \\
\text { infusion }\end{array}$ & $\begin{array}{l}750 \mathrm{mg} / \mathrm{m}^{2} ; \text { two doses } 2 \text { weeks apart } \\
\text { or } 375 \mathrm{mg} / \mathrm{m}^{2} ; \text { four doses, weekly } \times 4 \text {, } \\
\text { maximum } 1,000 \mathrm{mg} / \text { dose }\end{array}$ \\
\hline $\begin{array}{l}\text { Tocilizumab } \\
\text { (MRA) }\end{array}$ & IL-6 & No & $\begin{array}{l}\text { Intravenous } \\
\text { infusion }\end{array}$ & 8 to $12 \mathrm{mg} / \mathrm{kg}$ every 2 weeks \\
\hline
\end{tabular}

FDA, Food and Drug Administration.

considered in the context that only 20 out of the initial 69 patients enrolled in the original trial continued into the openlabel extension trial. Eleven of the patients who failed to respond during the initial drug run-in period withdrew, along with an additional 38 patients who withdrew from the study for a variety of reasons including lack of efficacy, adverse events, physician decision or patient refusal of ongoing participation [12].

Beyond this pivotal randomized controlled trial, much of the literature reporting efficacy of etanercept in JIA is from uncontrolled open-label trials and case series involving patients with polyarticular and systemic JIA refractory to standard DMARD treatments such as nonsteroidal antiinflammatory drugs and methotrexate. Despite the fact that these studies involve patients with difficult to treat disease, significant improvements have been noted. Recent data from the German JIA registry provided information on 431 children with various JIA subtypes treated either with etanercept alone or with the combination of etanercept and methotrexate (various regimens). At 12 months of follow up, $62 \%$ of patients receiving combination therapy achieved an ACR Pedi 70 response, while $45 \%$ of patients receiving etanercept alone achieved this response $(P$ for difference $<0.01)$. An ACR Pedi 30 response was observed in as many as $70 \%$ to $80 \%$ of patients receiving either etanercept regimen [13].

Similar results have been observed in the Dutch national registry of JIA patients receiving etanercept therapy. In a cohort of 146 patients with JIA (all subtypes) treated with etanercept $(0.8 \mathrm{mg} / \mathrm{kg} /$ week, divided twice weekly or once a week), 50\% achieved an ACR Pedi 70 response within the first 3 months of treatment and this response was sustained at 2 years of treatment. Responses waned somewhat after the 2-year mark, with approximately 30\% of children observed for 3 to 5 years sustaining or achieving the ACR Pedi 70 response [14]. Of note, the Dutch cohort contained a higher percentage of patients with systemic-onset disease than the German Registry. This is important as systemiconset patients may not respond as well to etanercept as children with other forms of JIA.

In both registries, etanercept had good short-term safety and tolerability. Nonserious adverse events including injection site reactions, upper respiratory tract infection and headaches were reported at an incidence or rate of 0.15 to 0.21 per patient-year, while serious adverse events such as bacterial infections, hospitalizations and malignancies occurred at a rate of 0.029 to 0.10 per patient-year in these two patient registries $[13,14]$.

\section{Infliximab}

Infliximab (Remicade) is a chimeric monoclonal antibody that combines human and mouse components to create a molecule with high affinity for TNF $\alpha$. Unlike etanercept, infliximab binds both soluble as well as membrane-bound TNF $\alpha$. Infliximab has FDA approval in the United States for a variety of indications, including adult rheumatoid arthritis, psoriasis, and adult and pediatric Crohn's disease (for 
children older than 6 years of age). Use in juvenile arthritis is not formally approved but remains a common application.

Results of an international, multicenter, randomized controlled trial of infliximab combined with methotrexate for the treatment of polyarticular JIA have been published recently [15]. This collaborative study by the Pediatric Rheumatology International Trials Organization and the Pediatric Rheumatology Collaborative Study Group enrolled 122 children with polyarticular JIA refractory to methotrexate alone, and randomized subjects to either infliximab ( $3 \mathrm{mg} / \mathrm{kg} /$ dose) or placebo for 14 weeks, followed by an active treatment extension period at one of two infliximab dosages $(3 \mathrm{mg} / \mathrm{kg}$ or $6 \mathrm{mg} / \mathrm{kg}$ ). At 14 weeks, a higher proportion of patients randomized to infliximab had an ACR Pedi 30 response than in the placebo group; however, this difference was not statistically significant. Over the open-label treatment period, patient responses to infliximab were similar to the results that have been reported with etanercept, with $70 \%$ and $52 \%$ of children achieving ACR Pedi 50 and ACR Pedi 70 responses by the end of 1 year [15].

In addition to the adverse effects reported with etanercept, infliximab treatment carries the added risk of infusion reactions. Patients may experience mild infusion-related symptoms ranging from rash and headache to more serious anaphylactic responses. These reactions are possibly due to immune responses against the mostly humanized mouse monoclonal antibody. The development of human antichimeric antibodies generated against infliximab has also been implicated in cases where infliximab effectiveness wanes over time [16]. In the Pediatric Rheumatology International Trials Organization/Pediatric Rheumatology Collaborative Study Group trial, infusion reactions occurred in approximately $26 \%$ of patients over the course of the active extension portion of the trial and were more frequent in patients treated with the lower $3 \mathrm{mg} / \mathrm{kg}$ dosage than at the $6 \mathrm{mg} / \mathrm{kg}$ dose [15]. An Italian registry including 68 children with JIA treated with infliximab similarly reported infusion reactions in up to $38 \%$ of patients, which lead to treatment discontinuation in $20 \%$ of patients [17]. Based on these findings, 6 to $10 \mathrm{mg} / \mathrm{kg}$ is now the recommended infliximab dosage range in children.

\section{Adalimumab}

Adalimumab (Humira) is the second TNF $\alpha$ antagonist to receive FDA approval for treatment of moderate to severe active polyarticular JIA in patients 4 years and older. Adalimumab is a fully humanized monoclonal antibody that binds soluble and membrane-bound TNF $\alpha$.

Results of a phase III randomized, double-blind, placebocontrolled study of adalimumab have been recently published [18]. This study enrolled 171 patients with polyarticular JIA who were either methotrexate naïve or had an inadequate response to methotrexate in a 4-month open-label run-in treatment with subcutaneous adalimumab $\left(24 \mathrm{mg} / \mathrm{m}^{2}\right.$, maximum $40 \mathrm{mg}$, every other week). Responders were then randomized to a placebo-controlled randomized drug withdrawal phase lasting 32 weeks. Patients randomized to placebo who experienced disease flares were eligible for an open-label extension trial. Results indicated response rates and tolerability similar to those observed for etanercept and infliximab. In particular, during the drug withdrawal phase, a significantly greater proportion of patients in the placebo group experienced disease flare than among patients receiving ongoing adalimumab $(71 \%$ versus $43 \%$ of subjects among nonmethotrexate-treated patients, $P=0.03 ; 65 \%$ versus $37 \%$ among patients receiving concomitant methotrexate, $P=0.02)$. After 104 weeks of open-label extension treatment, $86 \%$ of 128 patients achieved an ACR Pedi 50 response, $77 \%$ achieved an ACR Pedi 70 response and 40\% achieved an ACR Pedi 100 response [18]. In terms of safety and tolerability, serious adverse events (SAE) attributed to the study drug including infections, disease flare and abdominal symptoms occurred in 14 patients, and overall SAE rates were less than 0.1 per patient-year of exposure. Additional reports of safety and tolerability of adalimumab from the ongoing open-label extension trial are expected (ClinicalTrials.gov identifier: NCT00048542).

It is thought that the three TNF $\alpha$ antagonist agents will share a similar long-term side effect. Postmarketing surveillance has demonstrated increased risks of abscess formation and sepsis in children. In adults, reactivation of latent tuberculosis infection as well as rare reports of demyelinating disorders such as optic neuritis and multiple sclerosis have been associated with TNF $\alpha$-blocking therapy. Given the immunomodulatory effect of TNF $\alpha$ antagonists, concern for development of novel autoantibodies has also arisen. In the infliximab randomized controlled trial, newly positive antinuclear antibodies occurred in 8 out of 54 patients and in 1 out of 46 patients treated at the $3 \mathrm{mg} / \mathrm{kg}$ and $6 \mathrm{mg} / \mathrm{kg}$ doses, respectively, but did not seem to be of clinical significance [15]. This issue has also been studied in detail in a small cohort of children receiving either etanercept or infliximab therapy for $\geq 2$ years. Serologic evidence of new anti-smooth muscle, anti-reticulin or thyroid autoantibodies was detected in 6 out of 26 patients studied, and these autoantibodies persisted over 12 to 50 months. Most patients remained asymptomatic, with the exception of one new case of Hashimoto's thyroiditis concomitant with development of antithyroid antibodies [19].

Additional data concerning long-term safety of TNF $\alpha$ antagonists are provided by the interim results of an openlabel, multicenter registry of etanercept with or without methotrexate in children with polyarticular or systemic JIA, which were presented in abstract form at the 2008 American College of Rheumatology Keystone Pediatric Rheumatology Symposium [20]. Patients were enrolled into one of three study arms: methotrexate monotherapy (198 subjects), 
etanercept monotherapy (105 subjects) or etanercept plus methotrexate therapy (299 subjects) for a total of 1,208 patient-years of exposure over the course of the 3-year study. Rates of serious adverse events as well as overall adverse events and new autoantibody formation were similar in all three treatment groups. Serious infections occurred at a rate of 0.01 to 0.02 events per patient-year of exposure. No cases of tuberculosis, lymphoma or malignancy were observed [20].

Extensive data regarding the risk of malignancy in children exposed to TNF $\alpha$ inhibitors are still not available. In June 2008 the FDA released an early communication about an ongoing review of 30 cases of cancer detected among children receiving TNF $\alpha$ blockers (along with other immunosuppressive medications) for a variety of indications. It is unclear, however, whether or not this represents an increase over the baseline rate that would be expected in children.

\section{IL-1 antagonists}

IL-1 is a proinflammatory cytokine that mediates diverse effects such as cartilage degradation and bone resorption. One IL-1-blocking agent is currently in use in children with JIA, while several other IL-1-blocking therapeutics are under development.

\section{Anakinra}

Anakinra (Kineret) is a recombinant form of the human IL-1 receptor antagonist. It competitively binds to the IL-1 receptor and thus blocks endogenous IL-1 signaling. Anakinra was the first IL-1 receptor antagonist developed for clinical use, and to date is FDA-approved for treatment of adult RA. Anakinra is a short-acting agent that requires daily subcutaneous injections. Responses to anakinra in most adult patients with RA have been somewhat discouraging. Data surrounding anakinra in pediatric JIA are limited. A recent randomized controlled trial trial of anakinra $(1 \mathrm{mg} / \mathrm{kg} /$ day; maximum $100 \mathrm{mg} /$ day) versus placebo in 50 patients with JIA was unable to demonstrate significant efficacy of the drug. Subgroup analysis in this trial, however, suggested that response rates may be higher among patients with SOJIA [21]. This finding parallels anecdotal reports of beneficial effects of anakinra in SOJIA patients as well as protein expression profiling studies indicating that IL-1 expression is upregulated in patients with SOJIA and may be important in disease pathogenesis for this subtype in particular [22]. Indeed, an initial case series reported by Pascual and colleagues reported a dramatic response to IL-1 blockade among SOJIA patients, with seven out of nine patients treated with anakinra achieving complete remission of their disease [22].

A recent retrospective case series by Lequerre and colleagues measured ACR Pedi 30, ACR Pedi 50 and ACR Pedi 70 responses and adverse events in 20 patients with SOJIA treated with anakinra (1 to $2 \mathrm{mg} / \mathrm{kg} /$ day, maximum $100 \mathrm{mg}$ ) [23]. All patients had been refractory to previous medications, including TNF $\alpha$ antagonists in many cases. Fifteen out of 20 patients showed an initial partial response to anakinra, with improvement in both systemic features, including fever and rash, and laboratory features of SOJIA. By the 3-month follow-up, however, the SOJIA patients were divided equally into responders and nonresponders. In the 10 patients who had a positive response to anakinra, improvement continued over the course of the first 6 months of treatment. Six out of these 10 patients achieved an ACR Pedi 50 or greater response, while the remaining four patients achieved a $30 \%$ improvement response [23].

This heterogeneous response to anakinra was duplicated in another open-label trial conducted by Gattorno and colleagues [24]. In their prospective study, 22 patients with severe SOJIA were treated with anakinra ( 1 to $4 \mathrm{mg} / \mathrm{kg} /$ day). One-half of the patients had a dramatic improvement in symptoms and laboratory parameters, which was observed within the first few weeks of treatment. Eleven patients exhibited incomplete or no response. Based on these findings, the authors suggest there may be two distinct phenotypes of SOJIA patients based on IL-1 response [24].

Injection pain and local injection site reactions are frequent side effects of anakinra, although the intensity of injection site reactions has been reported to decrease over time [21]. Similar to TNF $\alpha$ blocking agents, IL-1 blockade raises concern for increased infection risk as well as unknown longer term effects on the immune system. In Lequerre and colleagues' cohort of 20 patients, two serious infections were noted over the course of the first year of therapy [23]. There have also been anecdotal reports of tachyphylaxis to anakinra as well as severe disease rebound with abrupt drug continuation. In Gattorno and colleagues' series, two patients experienced a severe disease flare known as macrophage activation syndrome (MAS) within 13 days of anakinra treatment [24]. Refractory SOJIA patients are known to be at high risk for MAS, however, and this complication may have been coincidental with drug initiation. Without well-designed trials, the attributability of these findings remains unclear and the ultimate long-term safety profile of anakinra needs to be determined. In this vein, a phase II/III double-blind, randomized, placebo-controlled trial of anakinra in refractory SOJIA followed by an open-label extension trial to assess tolerability and efficacy is underway (ClinicalTrials.gov Identifier: NCT00339157).

\section{Rilonacept}

Rilonacept (IL-1 Trap) is another IL-1-blocking agent currently undergoing trials in children with SOJIA. Rilonacept is a recombinant fusion protein that combines IL-1 receptor protein components with the Fc portion of the human immunoglobulin molecule. Unlike anakinra, which requires daily dosing, rilonacept is a longer-acting $\mathrm{IL}-1$ blocker and is administered once a week. Preliminary results of a doubleblind, placebo-controlled study of rilonacept $(2.2$ to 
$4.4 \mathrm{mg} / \mathrm{kg} /$ week) in SOJIA followed by an open-label extension trial were reported by Lovell and colleagues in abstract form at the 2007 American College of Rheumatology Scientific Meeting. Of the 21 patients enrolled in the trial, 12 remain in the open-label study and have had good responses to rilonacept - with 10 patients achieving an ACR Pedi 70 response at 42 weeks (median treatment period). Discontinuations were due to nonresponse or worsening of underlying disease, including one episode of MAS [25]. To further address the safety and efficacy of rilonacept, a larger follow-up trial known as the RAPPORT study is underway (ClinicalTrials.gov identifier: NCT005344950).

\section{ACZ885}

ACZ885 is a fully humanized monoclonal antibody which binds specifically to the $\beta$ isoform of IL-1 (IL-1 $\beta$ ) and blocks downstream effects of the molecule. The mechanism of action of ACZ885 thus differs from anakinra and rilonacept, which block signaling of both the IL- $1 \alpha$ and IL-1 $\beta$ forms. Animal models and in vitro studies suggest that IL-1 $\beta$ may the more potent inflammatory mediator of the two isoforms [22]. It is administered as either a subcutaneous injection or an intravenous infusion; the dosage, frequency and efficacy have yet to be established although preliminary trials in adult patients are underway. For children with JIA, an open-label phase I/II trial of ACZ885 in SOJIA is currently being conducted (ClinicalTrials.gov identifier: NCT00426218).

\begin{abstract}
Abatacept
Abatacept (Orencia) is a recombinant fusion protein with a unique mechanism of action. Abatacept consists of the Fc portion of the human immunoglobulin molecule combined with the extracellular portion of the cytotoxic T-lymphocyteassociated antigen 4 [26]. The drug binds tightly to the B7 domain on antigen-presenting cells, preventing generation of a costimulatory signal required for T-cell activation. Abatacept thus downregulates T-cell stimulation, leading to decreased B-cell and macrophage activation and to the modulation of multiple downstream inflammatory cytokine pathways that have been implicated in the pathogenesis of JIA.
\end{abstract}

In April 2008 abatacept received FDA approval for treatment of patients aged 6 years or older with moderate to severe polyarticular JIA. The pivotal study of abatacept in JIA enrolled patients with active polyarticular JIA refractory to at least one previous DMARD agent in a open-label 4-month lead-in treatment with active drug $(10 \mathrm{mg} / \mathrm{kg} /$ dose $)$ followed by a 6 month randomized, double-blinded, placebo-controlled drugwithdrawal phase and open-label extension [27]. Of the 190 patients enrolled, 123 patients (65\%) achieved an ACR Pedi 30 response or better in the lead-in phase and were randomized. During the double-blind phase, a significantly greater proportion of patients receiving placebo exhibited disease flare $(53 \%$ of 62 placebo-treated patients versus $20 \%$ of 60 abatacept-treated patients; $P=0.0003$ ) [27]. Short-term safety and tolerability of abatacept in pediatric patients appears to be good. Common adverse effects associated with abatacept include infusion reactions, headache, nausea, cough, diarrhea or upper respiratory infections. Although a slightly increased risk of serious infections has been noted in adult trials, there was no difference in serious events between abatacept-treated and placebo-treated groups in this pediatric study [27]. Longer term safety and efficacy are yet to be reported in pediatric populations, but an open-label extension trial is underway (ClinicalTrials.gov Identifier: NCT00095173).

\section{Rituximab}

Rituximab (Rituxan) is a chimeric monoclonal antibody to CD20, a cell surface marker found on mature B cells but not on stem or plasma (memory) cells. Binding of the monoclonal antibody to CD20 results in selective depletion of CD20positive B cells, but preserves progenitor and antibodyproducing cellular compartments [28]. B-cell depletion has emerged as a treatment possibility for various autoimmune disorders. Although the exact mechanisms of action in arthritis remains unclear, B-cell depletion may produce antiinflammatory effects via decreased antigen presentation and disruption of T-cell costimulation [29]. Rituximab has been shown to be effective in treatment of adult RA, but the role of the drug in clinical care remains to be clarified [30,31]. Rituximab currently has FDA approval for treatment of adult patients with moderate to severe active RA who have had inadequate response to one or more TNF $\alpha$-blocking agents. Reported adverse effects of rituximab include infusion reactions and serum sickness. Other complications include increased infection risks, and occasional cases of hypogammaglobulinemia [32]. Several humanized anti-B-cell monoclonal antibodies are currently under development, and trials in adult RA are underway.

To date there are only case reports and anecdotal experience with use of rituximab in children with severe refractory JIA $[29,33]$. The mechanism of action of rituximab raises unique safety concerns in children, especially in terms of vaccine responses and potential long-term effects of B-cell depletion. Studies of rituximab in children with conditions such as chronic autoimmune cytopenias, however, have provided preliminary evidence of safety and tolerability in children [34,35].

\section{Tocilizumab}

Tocilizumab (MRA) is a recombinant, humanized monoclonal antibody that binds to the IL- 6 receptor and blocks downstream signaling of IL-6, another proinflammatory cytokine. Plasma levels of IL- 6 have been demonstrated to correlate with disease activity in JIA patients, and particularly elevated IL-6 levels have been noted in patients with SOJIA $[10,36]$. Initial reports of ani-IL6 therapy in SOJIA have been promising.

Results of a phase III trial of tocilizumab $(8 \mathrm{mg} / \mathrm{kg}$ every 2 weeks) in SOJIA by Yokota and colleagues were published recently [37]. Fifty-six children with SOJIA were enrolled in 
the study, which utilized the drug-withdrawal design followed by an open-label extension phase. During the initial drug runin phase, 50 out of 56 patients achieved an ACR Pedi 30 response and were eligible for randomization. After the 12-week placebo-controlled randomization phase, $80 \%$ of patients randomized to active drug maintained an ACR Pedi 30 response or better, compared with $17 \%$ of patients in the placebo group. Results of the open-label extension period demonstrated that 43 out of 48 patients achieved an ACR Pedi 70 response at the end of 48 weeks of treatment. Adverse effects of tocilizumab included infusion reactions, gastrointestinal hemorrhage as well as infectious events. Severe adverse events occurred in 13 out of 50 patients during the open-label extension phase [37].

Studies of tocilizumab in adults with RA have also indicated elevations in serum cholesterol associated with drug administration [38]. This possibility needs to be further evaluated in pediatric populations. An international phase III trial of tocilizumab in SOJIA is underway in order to determine optimum dosing regimens and to further evaluate efficacy and safety (ClinicalTrials.gov identifier: NCT00642460).

\section{Other agents Leflunomide}

Leflunomide (Arava) is a novel isoxazol prodrug that is quickly metabolized to an active metabolite. The active metabolite reversibly inhibits the enzyme dihydroorotate dehydrogenase, which is required for pyrimidine nucleotide synthesis. This drug has an antiproliferative effect on T cells in vitro, but little is known about the mechanism of action in patients with inflammatory arthritis. Because of the very long half-life of the metabolite (about 2 weeks), a loading dose of $100 \mathrm{mg} /$ day for 3 days (in adult-sized patients) is used to facilitate rapid attainment of steady-state levels. The onset of effect may begin as early as 4 weeks after drug initiation, and improvement continues through about 5 months of treatment [39].

A cohort of patients with RA treated with leflunomide for 12 months demonstrated retardation in progression of X-ray damage [40]. In patients with JIA, leflunomide has also been demonstrated to be an effective treatment. A recent randomized controlled trial compared use of leflunomide (5 to $20 \mathrm{mg}$ daily based on weight cutoff values) or oral methotrexate $(0.5 \mathrm{mg} / \mathrm{kg} /$ week $)$ in 94 patients with active polyarticular JIA [41]. After 48 weeks of treatment, the ACR Pedi 30, ACR Pedi 50 and ACR Pedi 70 responses were similar between the two groups (79\%, 76\% and $70 \%$ for leflunomide, and $91 \%$, $86 \%$ and $83 \%$ for oral methotrexate). Adverse event frequencies were also similar between the two treatment groups.

The most commonly reported adverse reactions to leflunomide are gastrointestinal: diarrhea, anorexia, abdominal pain, gastritis and transaminitis. Other potential side effects include rash, allergic reactions, headache and reversible alopecia in approximately $5 \%$ to $10 \%$ of patients. Less common are weight loss and hypophosphatemia. Of note, neither leflunomide and its active metabolite are dialyzable, and drug metabolites are detectable in urine and feces for prolonged periods after chronic administration. Elimination can be hastened by the use of cholestyramine. Leflunomide is a known teratogen; there are no long-term studies to assess the carcinogenicity of leflunomide or its effect on fertility.

\section{Thalidomide}

Thalidomide is a unique immunomodulatory agent with antiangiogenesis effects in addition to inhibiting TNF $\alpha$ function. It is also thought to suppress other proinflammatory cytokines, to downregulate adhesion molecules as well as to inhibit leukocyte chemotaxis and decrease the CD4/CD8 T-cell ratio [42]. Evidence concerning use of thalidomide in JIA is limited to case series $[43,44]$. In the largest of these studies, Lehman and colleagues reported use of thalidomide ( 2 to $5 \mathrm{mg} / \mathrm{kg} /$ day) in 13 children with severe, refractory SOJIA. An ACR Pedi 50 response or better was noted in 10 out of 13 children treated, and six children were able to discontinue chronic prednisone [44]. Side effects including sedation, somnolence and neutropenia were observed. None of these patients experienced neurotoxicity; however, the possibility of permanent peripheral neuropathy is possible with long-term use. Some clinicians will therefore monitor nerve conduction studies in patients on thalidomide.

Lenalidomide (Revlimid) is a novel thalidomide-based drug with enhanced immunomodulatory properties and an improved neurologic safety profile [45]. There is no published documentation of use in JIA at this time. Both lenalidomide and thalidomide are very potent teratogens, and birth control is necessary for both males and females. The use of both medications is tightly controlled through the manufacturer, Celgene, which requires licensure for prescribers as well as specific patient education, consent and ongoing safety laboratory monitoring.

\section{Autologous stem cell transplant}

There are still subsets of JIA patients who fail to achieve disease control with any combination of medications. For certain of these patients, autologous stem cell transplantation may provide an option for disease remission.

Results from over 50 patients with refractory JIA who have undergone autologous stem cell transplantation at multiple centers across Europe have been published [46,47]. Different conditioning regimens were used, hampering interpretation of the results. Among 34 such patients followed for $>12$ months (range 12 to 60 months) after autologous stem cell transplantation, 18 patients $(53 \%)$ achieved a complete anti-rheumatic drug-free remission and an additional six patients (18\%) had a partial response (ACR Pedi 30 response or better). For seven patients (21\%), transplant was followed by disease relapse. Death occurred in five patients [46]. All transplant-related deaths occurred in patients with SOJIA who developed MAS complicated by infection. 
Autologous stem cell transplantation protocols were subsequently amended in 1999 to include the following: stem cell preparations are less completely T-cell depleted, SOJIA patients who have fever or evidence of MAS at the time of conditioning are excluded, routine anti-viral prophylaxis is initiated post transplant, and patients are carefully monitored for emerging MAS. Since these changes, there have been no further transplant-related deaths among 11 patients who have undergone autologous stem cell transplant with the modified regimen [47]. Significant morbidity is still associated with the period of prolonged immunosuppression after transplant, including a large number of viral and bacterial infections. Certain patients with refractory JIA have subsequently been able to lead disease-free lives off medication, however, which would not have been possible without autologous stem cell transplantation.

\section{Future directions}

New definitions of inactive disease and clinical remission have put the results of recent trials into perspective; less than $25 \%$ to $40 \%$ of patients achieved inactive disease on biologic medications. To date there have been no head-tohead efficacy trials of JIA treatments, nor long-term data on the safety of various medication combinations. Additionally, clinicians are unable to reliably predict patient responses to therapeutics, forcing refractory patients to undergo a lengthy trial-and-error approach to optimizing treatment.

Evidence is accumulating that early disease control may be important in determining long-term outcomes of patients with arthritis. Long-term follow-up studies of adult RA patients have demonstrated sustained reduction in joint damage and radiologic progression associated with early versus delayed treatment approaches [48]. In the pediatric literature, a recent long-term outcomes study of JIA patients previously enrolled in a randomized controlled trial of sulfasalazine versus placebo found that benefits of treatment response within the first 2 years of disease onset were sustained at follow-up years later [49]. This suggests there is a therapeutic window of opportunity in which to target interventions to optimize long-term outcomes in children with JIA.

A multicenter, randomized, placebo-controlled trial of treatment of polyarticular JIA with etanercept, prednisone and subcutaneous methotrexate versus subcutaneous methotrexate monotherapy is underway. Known as the Trial of Early Aggressive Drug Therapy in Juvenile Idiopathic Arthritis, this trial is investigating the importance of early aggressive treatment in improving JIA outcomes and is the first trial to use inactive disease as a primary endpoint (ClinicalTrials.gov Identifier: NCT00443430).

Although there are many exciting developments in the treatment of JIA, of great importance to patients, families and physicians are the potential long-term risks and benefits of these novel treatments in children with JIA. Long-term registries of JIA patients are necessary to answer these crucial questions.

\section{Competing interests}

CAW has received consulting fees, speaking fees, and/or honoraria (less than $\$ 10,000$ each) from Amgen, Pfizer, Novartis, and Bristol-Myers Squibb, and has received research grants (more than \$10,000 each) from Pfizer and Centocor. $\mathrm{KH}$ declares that they have no competing interests.

\section{References}

1. Helmick CG, Felson DT, Lawrence RC, Gabriel S, Hirsch R, Kwoh CK, Liang MH, Kremers HM, Mayes MD, Merkel PA, Pillemer SR, Reveille JD, Stone JH, National Arthritis Data Workgroup: Estimates of the prevalence of arthritis and other rheumatic conditions in the United States. Part I. Arthritis Rheum 2008, 58:15-25.

2. Petty RE, Southwood TR, Manners P, Baum J, Glass DN, Goldenberg J, He X, Maldonado-Cocco J, Orozco-Alcala J, Prieur AM, Suarez-Almazor ME, Woo P, International League of Associations for Rheumatology: International league of associations for rheumatology classification of juvenile idiopathic arthritis: second revision, Edmonton, 2001. J Rheumatol 2004, 31:390392.

3. Minden K, Kiessling U, Listing J, Niewerth M, Doring E, Meincke J, Schontube M, Zink A: Prognosis of patients with juvenile chronic arthritis and juvenile spondyloarthropathy. J Rheumatol 2000, 27:2256-2263.

4. Packham JC, Hall MA: Long-term follow-up of $\mathbf{2 4 6}$ adults with juvenile idiopathic arthritis: functional outcome. Rheumatology (Oxford) 2002, 41:1428-1435.

5. Wallace CA, Huang B, Bandeira M, Ravelli A, Giannini EH: Patterns of clinical remission in select categories of juvenile idiopathic arthritis. Arthritis Rheum 2005, 52:3554-3562.

6. Haines KA: Juvenile idiopathic arthritis: therapies in the 21st century. Bull NYU Hosp Jt Dis 2007, 65:205-211.

7. Hashkes PJ, Laxer RM: Medical treatment of juvenile idiopathic arthritis. JAMA 2005, 294:1671-1684.

8. Wallace CA: Current management of juvenile idiopathic arthritis. Best Pract Res Clin Rheumatol 2006, 20:279-300.

9. Ringold S, Wallace CA: Measuring clinical response and remission in juvenile idiopathic arthritis. Curr Opin Rheumatol 2007, 19:471-476.

10. Kutukculer N, Caglayan S, Aydogdu F: Study of pro-inflammatory (TNF- $\alpha$, IL-1 $\alpha$, IL-6) and T-cell-derived (IL-2, IL-4) cytokines in plasma and synovial fluid of patients with juvenile chronic arthritis: correlations with clinical and laboratory parameters. Clin Rheumatol 1998, 17:288-292.

11. Lovell DJ, Giannini EH, Reiff A, Cawkwell GD, Silverman ED, Nocton JJ, Stein LD, Gedalia A, llowite NT, Wallace CA, Whitmore J, Finck BK: Etanercept in children with polyarticular juvenile rheumatoid arthritis. pediatric rheumatology collaborative study group. N Engl J Med 2000, 342:763-769.

12. Lovell DJ, Reiff A, llowite NT, Wallace CA, Chon Y, Lin SL, Baumgartner SW, Giannini EH, Pediatric Rheumatology Collaborative Study Group: Safety and efficacy of up to eight years of continuous etanercept therapy in patients with juvenile rheumatoid arthritis. Arthritis Rheum 2008, 58:1496-1504.

13. Horneff G, De Bock F, Foeldvari I, Girschick HJ, Michels H, Moebius D, Schmeling $\mathrm{H}$ : Safety and efficacy of combination of etanercept and methotrexate compared to treatment with etanercept only in patients with juvenile idiopathic arthritis (JIA). Preliminary data from the German JIA registry. Ann Rheum Dis 2008 [Epub ahead or print].

14. Prince $F H$, Twilt $M$, Ten Cate $R$, van Rossum MA, Armbrust W, Hoppenreijs EP, van Santen-Hoeufft M, Koopman-Keernink Y, Wulffraat NM, van Suijlekom-Smit LW: Long-term follow-up on effectiveness and safety of etanercept in JIA: the Dutch national register. Ann Rheum Dis 2008, in press.

15. Ruperto N, Lovell DJ, Cuttica R, Wilkinson N, Woo P, Espada G, Wouters C, Silverman ED, Balogh Z, Henrickson M, Apaz MT, Baildam E, Fasth A, Gerloni V, Lahdenne P, Prieur AM, Ravelli A, Saurenmann RK, Gamir ML, Wulffraat N, Marodi L, Petty RE, Joos 
R, Zulian F, McCurdy D, Myones BL, Nagy K, Reuman P, Szer I, Travers S, Beutler A, Keenan G, Clark J, Visvanathan S, Fasanmade A, Raychaudhuri A, Mendelsohn A, Martini A, Giannini EH, Paediatric Rheumatology International Trials Organisation, Pediatric Rheumatology Collaborative Study Group: A randomized, placebo-controlled trial of infliximab plus methotrexate for the treatment of polyarticular-course juvenile rheumatoid arthritis. Arthritis Rheum 2007, 56:3096-3106.

16. van der Laken CJ, Voskuyl AE, Roos JC, Stigter van Walsum M, de Groot ER, Wolbink G, Dijkmans BA, Aarden LA: Imaging and serum analysis of immune complex formation of radiolabelled infliximab and anti-infliximab in responders and non-responders to therapy for rheumatoid arthritis. Ann Rheum Dis 2007, 66:253-256.

17. Gerloni V, Pontikaki I, Gattinara M, Fantini F: Focus on adverse events of TNF $\alpha$ blockade in JIA in an open monocentric longterm prospective study of $\mathbf{1 6 3}$ patients. Ann Rheum Dis 2008, 67:1145-1152

18. Lovell DJ, Ruperto N, Goodman S, Reiff A, Jung L, Jarosova K, Nemcova D, Mouy R, Sandborg C, Bohnsack J, Elewaut D, Foeldvari I, Gerloni V, Rovensky J, Minden K, Vehe RK, Weiner LW, Horneff G, Huppertz HI, Olson NY, Medich JR, Carcereri-De-Prati R, Mcllraith MJ, Giannini EH, Martini A, Pediatric Rheumatology Collaborative Study Group, Pediatric Rheumatology International Trials Organisation: Adalimumab with or without methotrexate in juvenile rheumatoid arthritis. N Engl J Med 2008, 359:810820.

19. Kanakoudi-Tsakalidou F, Tzimouli V, Pratsidou-Gertsi P, Chronopoulou $E$, Trachana $M$ : The significance of persistent newly developed autoantibodies in JIA patients under long-term anti-TNF treatment. Cytokine 2008, 42:293-297.

20. Giannini E, llowite N, Lovell D, Wallace C, Rabinovich C, Reiff A, Higgins G, Gottlieb B, Chon Y, Lin S-L: The long-term safety of etanercept $\left(\right.$ Enbrel $\left.^{\circledR}\right)$ in children with polyarticular or systemic juvenile rheumatoid arthritis. Interim results of a 3-year, openlabel registry [oral presentation]. ACR Keystone Pediatric Rheumatology Symposium; 1-5 March 2008; Keystone.

21. llowite N, Porras O, Reiff A, Rudge S, Punaro M, Martin A, Allen R, Harville T, Sun YN, Bevirt T, Aras G, Appleton B: Anakinra in the treatment of polyarticular-course juvenile rheumatoid arthritis: safety and preliminary efficacy results of a randomized multicenter study. Clin Rheumatol 2009, 28:129-137.

22. Pascual V, Allantaz F, Arce E, Punaro M, Banchereau J: Role of interleukin-1 (IL-1) in the pathogenesis of systemic onset juvenile idiopathic arthritis and clinical response to IL-1 blockade. J Exp Med 2005, 201:1479-1486.

23. Lequerre T, Quartier $P$, Rosellini D, Alaoui F, De Bandt M, Mejiad O, Kone-Paut I, Michel M, Dernis E, Khellaf M, Limal N, Job-Deslandre C, Fautrel B, Le Loet X, Sibilia J, Societe Francophone pour la Rhumatologie et les Maladies Inflammatoires en Pediatrie (SOFREMIP), Club Rhumatismes et Inflammation (CRI): Interleukin-1 receptor antagonist (anakinra) treatment in patients with systemic-onset juvenile idiopathic arthritis or adult onset still disease: preliminary experience in France. Ann Rheum Dis 2008, 67:302-308.

24. Gattorno M, Piccini A, Lasiglie D, Tassi S, Brisca G, Carta S, Delfino L, Ferlito F, Pelagatti MA, Caroli F, Buoncompagni A, Viola S, Loy A, Sironi M, Vecchi A, Ravelli A, Martini A, Rubartelli A: The pattern of response to anti-interleukin-1 treatment distinguishes two subsets of patients with systemic-onset juvenile idiopathic arthritis. Arthritis Rheum 2008, 58:1505-1515.

25. Lovell DJ, Giannini EH, Kimura Y, Li S, Hashkes PJ, Reiff AO, Wallace CA, Onel KB, Wei Y, FuryW, Nadler DR, Biedermann S, Osgood G, Papadopoulos JH, Radin AR: Preliminary evidence for sustained bioactivity of IL-1 trap (rilonacept), A long acting IL-1 inhibitor, in systemic onset juvenile idiopathic arthritis (SJIA) [abstract]. Arthritis Rheum 2007, 56:S514.

26. Sho M, Yamada A, Najafian N, Salama AD, Harada $H$, Sandner SE, Sanchez-Fueyo A, Zheng XX, Strom TB, Sayegh MH: Physiological mechanisms of regulating alloimmunity: cytokines, CTLA-4, CD25 ${ }^{+}$cells, and the alloreactive T cell clone size. $J$ Immunol 2002, 169:3744-3751.

27. Ruperto N, Lovell DJ, Quartier P, Paz E, Rubio-Perez N, Silva CA, Abud-Mendoza C, Burgos-Vargas R, Gerloni V, Melo-Gomes JA, Saad-Magalhaes C, Sztajnbok F, Goldenstein-Schainberg C, Scheinberg M, Penades IC, Fischbach M, Orozco J, Hashkes PJ, Hom C, Jung L, Lepore L, Oliveira S, Wallace CA, Sigal LH, Block
AJ, Covucci A, Martini A, Giannini EH, Paediatric Rheumatology INternational Trials Organization, Pediatric Rheumatology Collaborative Study Group: Abatacept in children with juvenile idiopathic arthritis: a randomised, double-blind, placebo-controlled withdrawal trial. Lancet 2008, 372:383-391.

28. Emery P, Fleischmann R, Filipowicz-Sosnowska A, Schechtman J, Szczepanski L, Kavanaugh A, Racewicz AJ, van Vollenhoven RF, Li NF, Agarwal S, Hessey EW, Shaw TM, DANCER Study Group: The efficacy and safety of rituximab in patients with active rheumatoid arthritis despite methotrexate treatment: results of a phase IIB randomized, double-blind, placebo-controlled, dose-ranging trial. Arthritis Rheum 2006, 54:1390-1400.

29. El-Hallak M, Binstadt BA, Leichtner AM, Bennett CM, Neufeld EJ, Fuhlbrigge RC, Zurakowski D, Sundel RP: Clinical effects and safety of rituximab for treatment of refractory pediatric autoimmune diseases. J Pediatr 2007, 150:376-382.

30. Keystone EC, Emery P, Peterfy CG, Tak PP, Cohen S, Genovese MC, Dougados M, Burmester GR, Greenwald M, Kvien TK Williams S, Hagerty D, Cravets MW, Shaw T: Rituximab inhibits structural joint damage in rheumatoid arthritis patients with an inadequate response to tumour necrosis factor inhibitor therapies. Ann Rheum Dis 2008 [Epub ahead or print]

31. McGonagle D, Tan AL, Madden J, Taylor L, Emery P: Rituximab use in everyday clinical practice as a first-line biologic therapy for the treatment of DMARD-resistant rheumatoid arthritis. Rheumatology (Oxford) 2008, 47:865-867.

32. Cohen SB, Emery P, Greenwald MW, Dougados M, Furie RA, Genovese MC, Keystone EC, Loveless JE, Burmester GR, Cravets MW, Hessey EW, Shaw T, Totoritis MC, REFLEX Trial Group: Rituximab for rheumatoid arthritis refractory to antitumor necrosis factor therapy: results of a multicenter, randomized, double-blind, placebo-controlled, phase III trial evaluating primary efficacy and safety at twenty-four weeks. Arthritis Rheum 2006, 54:2793-2806.

33. Kuek A, Hazleman BL, Gaston JH, Ostor AJ: Successful treatment of refractory polyarticular juvenile idiopathic arthritis with rituximab. Rheumatology (Oxford) 2006, 45:1448-1449.

34. Bennett CM, Rogers ZR, Kinnamon DD, Bussel JB, Mahoney DH, Abshire TC, Sawaf H, Moore TB, Loh ML, Glader BE, McCarthy MC, Mueller BU, Olson TA, Lorenzana AN, Mentzer WC, Buchanan GR, Feldman HA, Neufeld EJ: Prospective phase 1/2 study of rituximab in childhood and adolescent chronic immune thrombocytopenic purpura. Blood 2006, 107:26392642.

35. Rao A, Kelly M, Musselman M, Ramadas J, Wilson D, Grossman W, Shenoy S: Safety, efficacy, and immune reconstitution after rituximab therapy in pediatric patients with chronic or refractory hematologic autoimmune cytopenias. Pediatr Blood Cancer 2008, 50:822-825.

36. Yilmaz M, Kendirli SG, Altintas D, Bingol G, Antmen B: Cytokine levels in serum of patients with juvenile rheumatoid arthritis. Clin Rheumatol 2001, 20:30-35.

37. Yokota S, Imagawa T, Mori M, Miyamae T, Aihara Y, Takei S, Iwata $\mathrm{N}$, Umebayashi H, Murata T, Miyoshi M, Tomiita M, Nishimoto N, Kishimoto T: Efficacy and safety of tocilizumab in patients with systemic-onset juvenile idiopathic arthritis: a randomised, double-blind, placebo-controlled, withdrawal phase III trial. Lancet 2008, 371:998-1006.

38. Genovese MC, McKay JD, Nasonov EL, Mysler EF, da Silva NA Alecock E, Woodworth T, Gomez-Reino JJ: Interleukin-6 receptor inhibition with tocilizumab reduces disease activity in rheumatoid arthritis with inadequate response to diseasemodifying antirheumatic drugs: the tocilizumab in combination with traditional disease-modifying antirheumatic drug therapy study. Arthritis Rheum 2008, 58:2968-2980.

39. van Roon EN, Hoekstra M, Tobi $\mathrm{H}$, Jansen TL, Bernelot Moens $\mathrm{HJ}$ Brouwers JR, van de Laar MA: Leflunomide in the treatment of rheumatoid arthritis. An analysis of predictors for treatment continuation. Br J Clin Pharmaco/ 2005, 60:319-325.

40. Kaltwasser JP, Behrens F. Leflunomide: Long-term clinical experience and new uses. Expert Opin Pharmacother 2005, 6:787801.

41. Silverman E, Mouy R, Spiegel L, Jung LK, Saurenmann RK, Lahdenne P, Horneff G, Calvo I, Szer IS, Simpson K, Stewart JA Strand V, Leflunomide in Juvenile Rheumatoid Arthritis (JRA) Investigator Group: Leflunomide or methotrexate for juvenile rheumatoid arthritis. N Engl J Med 2005, 352:1655-1666. 
42. Vallet S, Palumbo A, Raje N, Boccadoro M, Anderson KC: Thalidomide and lenalidomide: mechanism-based potential drug combinations. Leuk Lymphoma 2008, 49:1238-1245.

43. Garcia-Carrasco M, Fuentes-Alexandro S, Escarcega RO, RojasRodriguez J, Escobar LE: Efficacy of thalidomide in systemic onset juvenile rheumatoid arthritis. Joint Bone Spine 2007, 74: 500-503.

44. Lehman TJ, Schechter SJ, Sundel RP, Oliveira SK, Huttenlocher A, Onel KB: Thalidomide for severe systemic onset juvenile rheumatoid arthritis: a multicenter study. J Pediatr 2004, 145: 856-857.

45. Chanan-Khan AA, Cheson BD: Lenalidomide for the treatment of B-cell malignancies. J Clin Oncol 2008, 26:1544-1552.

46. De Kleer IM, Brinkman DM, Ferster A, Abinun M, Quartier $P$, Van Der Net J, Ten Cate R, Wedderburn LR, Horneff G, Oppermann J, Zintl F, Foster HE, Prieur AM, Fasth A, Van Rossum MA, Kuis W, Wulffraat NM: Autologous stem cell transplantation for refractory juvenile idiopathic arthritis: analysis of clinical effects, mortality, and transplant related morbidity. Ann Rheum Dis 2004, 63:1318-1326.

47. Brinkman DM, de Kleer IM, ten Cate R, van Rossum MA, Bekkering WP, Fasth A, van Tol MJ, Kuis W, Wulffraat NM, Vossen JM: Autologous stem cell transplantation in children with severe progressive systemic or polyarticular juvenile idiopathic arthritis: long-term follow-up of a prospective clinical trial. Arthritis Rheum 2007, 56:2410-2421.

48. Raza K, Buckley CE, Salmon M, Buckley CD: Treating very early rheumatoid arthritis. Best Pract Res Clin Rheumatol 2006, 20: 849-863.

49. van Rossum $M A$, van Soesbergen $R M$, Boers $M, Z$ winderman $A H$, Fiselier TJ, Franssen MJ, ten Cate R, van Suijlekom-Smit LW, Wulffraat NM, van Luijk WH, Oostveen JC, Kuis W, Dijkmans BA, Dutch Juvenile Idiopathic Arthritis Study group: Long-term outcome of juvenile idiopathic arthritis following a placebocontrolled trial: sustained benefits of early sulfasalazine treatment. Ann Rheum Dis 2007, 66:1518-1524.

50. Giannini EH, Ruperto N, Ravelli A, Lovell DJ, Felson DT, Martini A: Preliminary definition of improvement in juvenile arthritis. Arthritis Rheum 1997, 40:1202-1209.

51. Brunner HI, Lovell DJ, Finck BK, Giannini EH: Preliminary definition of disease flare in juvenile rheumatoid arthritis. J Rheumatol 2002, 29:1058-1064.

52. Wallace CA, Ruperto N, Giannini E, Childhood Arthritis and Rheumatology Research Alliance, Pediatric Rheumatology International Trials Organization, Pediatric Rheumatology Collaborative Study Group: Preliminary criteria for clinical remission for select categories of juvenile idiopathic arthritis. J Rheumatol 2004, 31:2290-2294. 